UDC 6-61-613

DOI: $10.21668 /$ health.risk/2018.2.01.eng

Read

\title{
CONTEMPORARY TRENDS IN HARMONIZATION OF LEGAL GROUNDS FOR PROVIDING SAFETY OF ENVIRONMENTAL CHEMICAL CONTAMINAITON FOR HUMAN HEALTH
}

\author{
Z.I. Zholdakova, O.O. Sinitsyna, I.A. Pechnikova, O.N. Savostikova \\ Centre for Strategic Planning and Management of Biomedical Health Risks, Russian Ministry of Health, 10 \\ Pogodinskaya Str., Bldg. 1, Moscow, 119121, Russian Federation
}

Regulatory documents on environmental protection adopted in Russia and abroad often contradict each other as regards terms and requirements. It is even more so in case of subordinate legislation in Russia which often doesn't fully conform to international requirements and is not sufficient when it comes to legal protection of people and the environment from sources of chemical threats. Our research goal was to compare international and Russian documents on environment protection and validate our suggestions on their harmonization. Such a concept as a "target" is not a quantitative characteristic for those threats for health which are caused by contamination with chemicals. The MPC validating system existing in Russia as well as types of standards accepted in the country are not in full conformity with international practices. Abroad there are no MPCs for water objects used for fishery. In Russia, the Federal Law issued on January 01, 2002 No. 7-FL "On environmental protection" contains a term "standards for the quality of the environment"; however, such standards don't exist, and there are no techniques for their development either in Russia or abroad. But still, it is vital to give grounds for ecological-hygienic standards allowing for a lifecycle of chemicals. The greatest discrepancies occur in lists of chemicals which are subject to control in various environmental objects; these lists are to be adjusted significantly in order to create a unified document on control with recommendations on choice of priority indexes. International regulatory documents recommend a system of the best available technologies (BAT) as a way to reduce chemicals emissions into the environment. And they also state that in case it is impossible to meet safety requirements even with BAT application, then any permission to emit and discharge should contain a program on emissions reduction in future. However, there is no such requirement in Russian legislation; that is, MPC is replaced with technologies for emissions reduction. Therefore, it is necessary to work out a unified consistent system of laws and subordinate legislation on providing health safety and protection from chemical contamination of the environment.

Key words: chemical contamination, environment, targets, maximum permissible concentration, BAT, priority chemicals, harmonization.

According to M.E. Dmitriev, the Partnership: "There are about 2.5 million President of 'New Economic Growth' regulatory documents in Russia...". Cur-

(C) Zholdakova Z.I., Sinitsyna O.O., Pechnikova I.A., Savostikova O.N., 2018

Zoya I. Zholdakova - Doctor of Medical Sciences, Professor, Leading Researcher at Laboratory for Ecological and Hygienic Assessment and Chemicals Toxicity Prediction (e-mail: labtox430@sysin.ru; tel.: +7 (499) 24671-73).

Oksana O. Sinitsyna - Doctor of Medical Sciences, Professor, membre of the Russian Academy of Sciences (e-mail: labtox430@mail.ru; tel.: +7 (985) 304-34-44).

Irina A. Pechnikova - Candidate of Medical Sciences, Senior Researcher at Laboratory for Ecological and Hygienic Assessment and Chemicals Toxicity Prediction (e-mail: labtox430@sysin.ru; tel.: +7 (499) 246-71-73).

Ol'ga N. Savostikova - Candidate of Medical Sciences, Academic Secretary (e-mail: niisysin@sysin.ru; tel.: +7 (499) 246-05-18). 
rently, at least 10 federal laws ${ }^{1}$ are devoted to the requirements for protecting human health from the effects of chemicals. All these documents are inconsistent and contradict each other in terms and requirements. This applies even more to by-laws, which, moreover, do not fully correspond to international requirements, and in some cases are insufficient in respect of legal protection of a human and environment from the sources of chemical danger. In the absence of a unifying legislative act, there are also no links between the main elements of legislation regulating the protection of health from chemicals effects. In this regard, the purpose of this study was to compare international and national documents in the field of environmental protection and substantiation of proposals for their harmonization in the following areas: terminology, the system of chemical standards, lists of indices under control, the best available technologies.

One of the most recent laws related to environmental protection is the Federal Law of 10.01.2002 No. 7-FZ (Ed., Dated December 31, 2017) "On Environmental Protection" ${ }^{2}$. In addition to the concept of "maximum permissible concentration" (MPC) of substances in the environment, it contains such terms as "limits", "best available technologies" (BAT), "technological" and "technical" standards. Therefore, it is advisable to consider the significance and applicability of these indices.

\footnotetext{
${ }^{1}$ Vodnyi kodeks Rossiiskoi Federatsii № 74-FZ ot 03.06.2006 g. (red. ot 29.07.2017 g.) [Water Code of the Russian Federation of 03.06 .2006 No. 74-FZ (as amended on July 29, 2017)]. Konsul'tantPlyus. Available at: http://www.consultant.ru/document/cons doc LAW 60683/ (11.03.2018) (in Russian).

Vozdushnyi kodeks Rossiiskoi Federatsii № 60-FZ ot 19.03.1997 g. (red. ot 31.12.2017) [Air Code of the Russian Federation of March 19, 1997 No. 60-FZ (as amended on December 31, 2017)]. Konsul'tantPlyus. Available at: http://www.consultant.ru/document/cons doc LAW 13744/ (11.03.2018) (in Russian).

Ob otkhodakh proizvodstva i potrebleniya: Federal'nyi zakon № 89-FZ ot 24.06.1998 g. (red. ot 31.12.2017 g.) (s izm. i dop., vstup. v silu s 01.01.2018 g.) [On Production and Consumption Wastes: Federal Law No. 89-FZ of June 24 , 1998 (as amended on December 31, 2017) (as amended and supplemented, effective from 01.01.2018]. Kodeks: elektronnyi fond pravovoi i normativno-tekhnicheskoi dokumentatsii. Available at: http://docs.cntd.ru/document/901711591 (11.03.2018) (in
} Russian).

O vodosnabzhenii i vodootvedenii: Federal'nyi zakon № 416-FZ ot 07.12.2011 g. (red. ot 29.07.2017 g.) [On Water Supply and Sanitation: Federal Law No. 416-FZ of 07.12.2011 (as amended on July 29, 2017)]. Zakony Rossiiskoi Federatsii. Available at: https://fzakon.ru/laws/federalnyy-zakon-ot-07.12.2011-n-416-fz/ (11.03.2018) (in Russian).

Ob okhrane atmosfernogo vozdukha: Federal'nyi zakon № 96-FZ ot 04.05.1999 g. (red. ot 13.07.2015 g.) [On Atmospheric Air Protection: Federal Law No. 96-FZ of 04.05 .1999 (as amended on July 13, 2015)]. Konsul'tantPlyus. Available at: http://www.consultant.ru/document/cons doc LAW 22971/ (11.03.2018) (in Russian).

Ob ekologicheskoi ekspertize: Federal'nyi zakon № 174-FZ ot 23.11.1995 g. (red. ot 28.12.2017) (s izm. i dop., vstup. v silu s 01.01.2018 g.) [On Ecological Expertise: Federal Law No. 174-FZ of November 23, 1995 (as amended on December 28, 2017) (as amended and supplemented, effective from 01/01/2018)]. Konsul'tantPlyus. Available at: http://www.consultant.ru/document/cons_doc_LAW_8515/655dd7dcb4a739eff184c49e586dc3ac5ad72ee2/(11.03.2018) (in Russian).

O sanitarno-epidemiologicheskom blagopoluchii naseleniya: Federal'nyi zakon № 52-FZ ot 30.03.1999 g. [On Sanitary and Epidemiological Welfare of the Population: Federal Law of 30.03 .1999 No. 52-FZ]. Kodeks: elektronnyi fond pravovoi $i$ normativno-tekhnicheskoi dokumentatsii. Available at: http://docs.cntd.ru/document/901729631 (11.03.2018) (in Russian).

O bezopasnom obrashchenii s pestitsidami i agrokhimikatami: Federal'nyi zakon № 109-FZ ot 19.07 .1997 g. (red. ot 17.04.2017 g.) [On Safe Handling of Pesticides and Agrochemicals: Federal Act No. 109-FZ of July 19, 1997 (as amended on April 17, 2017)]. Kodeks: elektronnyi fond pravovoi $i$ normativno-tekhnicheskoi dokumentatsii. Available at: http://docs.cntd.ru/document/9045962 (11.03.2018) (in Russian).

O promyshlennoi bezopasnosti opasnykh proizvodstvennykh ob"ektov: Federal'nyi zakon № 116-FZ ot 21.07 .1997 g. (red. ot 07.03.2017 g.) (s izm. i dop., vstup. v silu s 25.03.2017 g.) [On Industrial Safety of Hazardous Production Facilities: Federal Law No. 116-FZ of July 21, 1997 (as amended on March 7, 2017) (as amended and supplemented, effective from March 25, 2017)]. Kodeks: elektronnyi fond pravovoi i normativno-tekhnicheskoi dokumentatsii. Available at: http://docs.cntd.ru/document/9046058 (11.03.2018) (in Russian).

O zashchite naseleniya i territorii ot chrezvychainykh situatsii prirodnogo i tekhnogennogo kharaktera Federal'nyi zakon № 68 FZ ot 21.12.1994 g. [About the protection of the population and the territories against emergency situations of natural and technogenic nature. Federal Law of December 21, 1994 No. 68-FZ]. Konsul'tantPlyus. Available at: http://www.consultant.ru/document/cons doc_LAW_5295/(11.03.2018) (in Russian).

${ }^{2}$ Ob okhrane okruzhayushchei sredy: Federal'nyi zakon №7-FZ ot 10.01.2002 g. (red. ot 31.12.2017 g.) [On Environmental Protection: Federal Law of 10.01.2002 No. 7-FZ (as amended on December 31, 2017)]. ]. Konsul'tantPlyus. Available at: http://www.consultant.ru/document/cons doc LAW 34823/ (11.03.2018) (in Russian). 
The "limits", "technical" and "technological" standards are not directly related to the danger of chemicals for human health, so their discussion was not part of the study objects.

In addition, there is the concept of "target" index in global practice, which is interpreted in our country in different ways.

The term of a "target index" for ensuring chemical safety in international law aimed at protecting the environment is borrowed from economy, and characterizes the level of achievement of the goals set by management bodies, and the degree of approximation to their values describes the efficiency level of the measures taken.

For example, one of the important conditions for the implementation of Protocol on Water and Health to the 1992 [1] is the development of national targets in accordance with article 6, paragraph 2 (a). Water management activities should be aimed at preserving, first, the quantity and quality of water resources for future generations; secondly, at implementing measures to prevent water-borne diseases, primarily, infectious ones, which is more effective economically, than eliminating their consequences. The third principle is to ensure access to information and public involvement in the decision-making process aimed at improving the quality of drinking water supply for broad sectors of society.

Thus, targets at the international level are not considered as water quality norms or standards. They are a criterion for assessing achievement of the proper conditions for not only a safe, but also an optimized water supply for the population.

In Russia, the standards for the chemical quality of environment are the maximum permissible concentrations (MPCs) and time limits - SRL (Safety
Reference Level of a substance) and SRLI (Safe Reference Level of Impact), justified by accelerated methods.

At present, there are three systems of standards for water bodies: hygienic MPCs for water bodies' chemicals for domestic, drinking and cultural purposes; MPCs for fishery water facilities and the MPCs specified for pesticides which results in disputes and inconsistencies in assessing the risk of water pollution. There is no system of fishery MPCs in place, either in international documents or in any developed country. The "environmental quality standards" mentioned in the Federal Law No. 7FZ of January 10, 2002 (Ed. December 31, 2017) ${ }^{2}$ "On Environmental Protection" do not exist, and there are no methods for their development both in the national and global practice. MPCs for atmospheric air in populated areas are meant to protect public health and improperly applied to nature protection.

At the same time, a number of standards require revision, since they, being oldestablished, do not take into account the data on new types of specific effects of chemicals toxic actions. So, A.N. Sysin Research Institute of Human Ecology and Environmental Health, now a structural unit of the Federal State Institution "Centre for Strategic Planning and Management of Biomedical Health Risks", Ministry of Health of Russian Federation (hereinafter referred to as the Center) did work to harmonize the MPCs for several dozens of chemicals in water and atmospheric air with the international standards, taking into account their carcinogenic properties [2]. However, this work needs to be continued considering new approaches, including the international ones ${ }^{3}$, as well as new data on chemicals toxic properties.

A.N. Sysin Research Institute of $\mathrm{Hu}-$ man Ecology and Environmental Health 
developed proposals and methodic approaches to create a system of ecological and hygienic standards for chemicals concentrations in water, taking into account their life cycle [3]. Based thereupon, a methodology has been developed to justify regional standards for chemicals with due account for the comprehensive effect on a human body following an allowable daily dose [4]. However, an adoption of legislative and organizational decisions is required to implement such proposals and approaches.

For environmental pollution control, the lists of chemicals are being formed, and in determining them, the hazard characteristics are of great importance. Thus, a stability index as one of the leading criteria for chemicals hazard was established in the 1970s [5]. Then it was acknowledged at the international level that chemical compounds with high stability, property of cross-media transitions and spatial distributions pose a great danger. As a result, a list of 13 persistent organic pollutants (POPs) was approved at the UN level in the Environmental Program, followed by more than 50 persistent bioaccumulative toxins (PBTs) [6].

Rotterdam Convention on the Prior Informed Consent Procedure for Certain Hazardous Chemicals and Pesticides in International Trade provides for the prohibition or strict limitation of about 30 chemical compounds [7], and this list is constantly being updated.

The UN recommendations have been considered when approving the "Indicative list of the main pollutants to be taken into account when establishing emission limit values", given in the Directive of the European Parliament and the Council of the European Union 2008/1/EC of January 15,2008 on the integrated pollution prevention and control ${ }^{4}$. The list contains 13 groups of chemical compounds for atmospheric air, and 12 groups of substances for the aquatic environment without deciphering these groups of substances ${ }^{4}$. It is made taking into account enterprises and technologies specific to EU, but does not fully reflect the diversity of industrial enterprises and technologies located on the territory of Russia, and is not always detailed by chemicals nomenclature.

Each country has its own list of priority hazardous compounds. For example, drinking water in different countries is monitored by $15-30$ parameters. In the US, the Scorecard list contains 670 substances (without specifying the safe level), and ATSDR list (Agency for Toxic Substances and Disease Registry) list contains 275 substances [8]. At the same time, these lists serve as the guidelines.

The Directive of the European Parliament and the Council of the European Union of November 3, 1998 "On the quality of water intended for human consumption" $(98 / 83 / \mathrm{EC})^{5}$, Article 5 states that "Member States shall set values applicable to water intended for human consumption; The values shall not be less stringent than those set

${ }^{3}$ R.1.2.3156-13. Otsenka toksichnosti i opasnosti khimicheskikh veshchestv i ikh smesei dlya zdorov'ya cheloveka [Estimation of toxicity and danger of chemicals and their mixtures for human health]. Kodeks: elektronnyi fond pravovoi i normativno-tekhnicheskoi dokumentatsii. Available at: http://docs.cntd.ru/document/1200115595 (20.03.2018) (in Russian).

${ }^{4} \mathrm{O}$ kompleksnom predotvrashchenii i kontrole zagryaznenii (kodifitsirovannaya versiya): Direktiva ES № 2008/1/ES ot 15 yanvarya $2008 \mathrm{~g}$. [On the integrated pollution prevention and control (codified version): EU Directive of January 15, 2008 No. 2008/1/EC]. PRAVO ${ }^{R U}$. Available at: http://docs.pravo.ru/document/view/25520201 (20.03.2018) (in Russian).

${ }^{5} \mathrm{O}$ kachestve vody, prednaznachennoi dlya upotrebleniya lyud'mi (98/83/ES): Direktiva Evropeiskogo parlamenta i Soveta Evropeiskogo soyuza ot 03.11.1998 g. [On the quality of water intended for human consumption (98/83 / EC): Directive of the European Parliament and the Council of the European Union of 03.11.1998.] Kodeks: elektronnyi fond pravovoi $i$ normativno-tekhnicheskoi dokumentatsii. Available at: http://docs.cntd.ru/document/456029632 (16.03.2018) (in Russian). 
out in Annex 1; A Member State shall set values for additional parameters not included in Annex 1, where necessary the protection of human health within its national territory or part of it so requires".

Based on these guidelines, Russia issued a Decree of the Russian Federation Government ddt. 08.07.2015, No.1316-r "On approval of the list of pollutants to which the state regulation measures of environmental protection are applied" ${ }^{\prime 6}$. This list contains 160 chemicals and 94 radioactive isotopes for atmospheric air; 163 substances, 5 generalized indices and 81 isotopes for water bodies, and 59 chemicals and 4 isotopes for soil.

This List is of an abstract nature, since it contains neither MPC values, nor methods for determining substances, nor instructions in which cases substances should be determined by certain compounds.

From a comparative analysis of our own studies findings and the List14 it fol- lows that the substances lists do not completely coincide with the recommended EU documents for monitoring. In addition, the list contains a number of errors, both for the substances listed in it, and for their names. For example, it is necessary to control benz(a)pyrene content for air, but for water - no; as for hydrargyrum, it is specified as follows: "Hydrargyrum and its compounds," while for the other heavy metals and inorganic elements only their names are indicated; the list includes dioxins and furans instead of the actually dangerous polychlorinated dioxins and furans, and etc.

In Russia, there have been approved over 1,400 MPCs and about 500 SRLIs for substances concentrations in water ${ }^{7}$ about 700 MPCs and about 1,700 SRLs - in atmospheric air of the populated areas ${ }^{8}$, about 600 standards for pesticides ${ }^{9}$, which is considerably beyond the List presented. It should be emphasized that the standards were usually developed at the request of

\footnotetext{
${ }^{6} \mathrm{Ob}$ utverzhdenii perechnya zagryaznyayushchikh veshchestv, $\mathrm{v}$ otnoshenii kotorykh primenyayutsya mery gosudarstvennogo regulirovaniya v oblasti okhrany okruzhayushchei sredy: Rasporyazhenie Pravitel'stva RF № 1316-r ot 08.07.2015 g. [On approval of the list of pollutants to which the state regulation measures of environmental protection are applied: a Decree of the Russian Federation Government of 08/08/2015 N 1316-r]. GARANT. Available at: http://base.garant.ru/71126758/ (21.03.2018) (in Russian).

${ }^{7}$ GN 2.1.5.1315-03. Predel'no dopustimye kontsentratsii (PDK) khimicheskikh veshchestv v vode vodnykh ob"ektov khozyai-stvenno-pit'evogo i kul'turno-bytovogo vodopol'zovaniya (s izmeneniyami i dopolneniyami) [HS 2.1.5.1315-03. Maximum permissible concentration (MPC) of chemicals in water of the water bodies of domestic, drinking, cultural and household water use (with amendments and additions)]. Moscow, Federal Center for Hygiene and Epidemiology of Rospotrebnadzor, Publ. 2003,154 p. (in Russian).

GN 2.1.5.2307-07. Orientirovochnye dopustimye urovni (ODU) khimicheskikh veshchestv v vode vodnykh ob"ektov khozyaistvenno-pit'evogo i kul'turno-bytovogo vodopol'zovaniya [HS 2.1.5.2307-07. SRLI (Safe Reference Level of Impact of chemicals in water in water bodies for domestic, drinking and cultural and household water use]. Moscow, Federal Center for Hygiene and Epidemiology of Rospotrebnadzor, Publ., 2008, p. 48 (in Russian).

${ }^{8}$ GN 2.1.6.2309-07. Orientirovochnye bezopasnye urovni vozdeistviya (OBUV) zagryaznyayushchikh veshchestv v atmosfernom vozdukhe naselennykh mest [HS 2.1.6.2309-07. Safety Reference Level of a substance (SRL) for pollutants in the atmospheric air of the populated areas]. Kodeks: elektronnyi fond pravovoi i normativno-tekhnicheskoi dokumentatsii. Available at: http://docs.cntd.ru/document/902081964 (21.03.2018) (in Russian).

Ob utverzhdenii gigienicheskikh normativov GN 2.1.6.3492-17 «Predel'no dopustimye kontsentratsii (PDK) zagryaznyayushchikh veshchestv $\mathrm{v}$ atmosfernom vozdukhe gorodskikh i sel'skikh poselenii»: Postanovlenie glavnogo gosudarstvennogo sanitarnogo vracha RF № 165 ot 22.12.2017 g [On Approval of Hygienic Standards HS 2.1.6.3492-17 "Maximum permissible concentrations (MPC) for pollutants in the atmospheric air of urban and rural settlements": Resolution of the Chief State Sanitary Doctor of the Russian Federation No. 165 of December 22, 2017]. Kodeks: elektronnyi fond pravovoi i normativnotekhnicheskoi dokumentatsii. Available at: http://docs.cntd.ru/document/556185926 (22.03.2018) (in Russian).

${ }^{9} \mathrm{Ob}$ utverzhdenii GN 1.2.3111-13 «Gigienicheskie normativy soderzhaniya pestitsidov v ob"ektakh okruzhayushchei sredy (perechen')» (s izmeneniyami na 13 iyulya 2016 goda): Postanovlenie glavnogo gosudarstvennogo sanitarnogo vracha RF № 55 ot 21.10.2013 g. [On Approval of HS 1.2.3111-13 "Hygienic standards for the content of pesticides in environmental objects (list)" (as amended on July 13, 2016): Decree of the Chief State Sanitary Doctor of the Russian Federation No. 55 of October 21, 2013]. Kodeks: elektronnyi fond pravovoi $i$ normativno-tekhnicheskoi dokumentatsii. Available at: http://docs.cntd.ru/document/499057253 (22.03.2018) (in Russian).
} 
enterprises polluting the environment through emissions and discharges, as well as organizations offering chemical products for use in various fields of activity. This indicates that the substances, for which standards are established, actually pollute the environment, and can pose a danger to human health, so the lack of control over their content is unacceptable.

It is obvious that all substances specified in the RF Government Decree of 08.07.2015 No. 1316-r and in the lists of hygienic standards for substances are inappropriate and impossible to be controlled. Therefore, surveillance authorities often reduce the number of indices. For example, according to the retrospective analysis data submitted by Moscow Government, the water quality control for Moskva River is carried out by at least 3 organizations: Moscow Department for Environmental Management and Protection, "Mosvodokanal" and "Mosvodostok". At the same time, the number of parameters controlled by these organizations ranges from 25 to 42, with the list of indices mainly consisting of inorganic substances, while certain organic substances and composite indexes are undifferentiated, and do not reflect the features of wastewater discharges in Moscow [9].

So, for an adequate control of emissions and discharges, recommendations have been developed for selecting the most dangerous indices ${ }^{10}$.

As can be seen from the table, the list of criteria for selection of the priority indices to be monitored is given in the Guidance to UNECE Protocol on Pollutant Release and Transfer Registers to "Convention on Access to Information, Public Participation in Decision-making and Access to Justice in Environmental Matters (1998) "[10] in terms of major toxicological criteria corresponds to the one approved in our country, and expanded with respect to some environmental, economic and geographical indicators (Table).

In our institution, studies were carried out [11], which made it possible to identify the priority indices of the pollution with effluents discharged into water bodies by the operating enterprises of eleven industries [12].

In consideration of the foregoing, it becomes evident that the lists of various levels indices under control are subject to significant adjustment with a view to creating a single control document that includes guidelines for selecting the priority indices.

At present, Russia introduces an assessment system for chemicals emissions based on the best available technologies index. This system is in line with international regulatory documents. Thus, according to the Directive of the European Parliament and Council of the European Union 2008/1/EC "Best Available Techniques (BAT) means the most effective and advanced stage in the development of activities and their methods of operation which indicate the practical suitability of particular techniques for providing in principle the basis for emission limit values designed to prevent and, where that is not practicable, generally to reduce emissions and the impact on the environment as a whole". Paragraph 20 states: "When an environmental

\footnotetext{
${ }^{10}$ SanPiN 2.1.5.980-00. Gigienicheskie trebovaniya k okhrane poverkhnostnykh vod [SanPiN 2.1.5.980-00. Hygienic requirements for surface waters protection]. Kodeks: elektronnyi fond pravovoi i normativno-tekhnicheskoi dokumentatsii. Available at: http://docs.cntd.ru/document/1200006938 (20.03.2018) (in Russian).

SanPiN 2.1.6.1032-01. Gigienicheskie trebovaniya k obespecheniyu kachestva atmosfernogo vozdukha naselennykh mest [SanPiN 2.1.6.1032-01. Hygienic requirements for quality assurance of atmospheric air in inhabited areas]. Kodeks: elektronnyi fond pravovoi i normativno-tekhnicheskoi dokumentatsii. Available at: http://docs.cntd.ru/document/901787814 (20.03.2018) (in Russian).
} 
Criteria for selecting priority indices for emissions into environment

\begin{tabular}{|c|c|}
\hline $\begin{array}{l}\text { Criteria for the selection of priority pollu- } \\
\text { tants (UN UNECE) [10] }\end{array}$ & $\begin{array}{c}\text { Criteria for the selection of priority regional indices for water } \\
\text { quality control (RF) }\end{array}$ \\
\hline $\begin{array}{l}\text { 1. Type of pollution source } \\
\text { 2. Composition of contamination } \\
\text { 3. Amount of pollutant delivered to the } \\
\text { environment } \\
\text { 4. Polluted objects of the environment } \\
\text { 5. Geographical range of pollution } \\
\text { 6. Stability } \\
\text { 7. Bioaccumulation } \\
\text { 8. Acute, subacute and chronic toxicity } \\
\text { for humans and animals } \\
\text { 9. Ecotoxicity } \\
\text { 10. Carcinogenicity } \\
\text { 11. Teratogenicity }\end{array}$ & $\begin{array}{l}\text { 1. Substance specificity } \\
\text { 2. Substance MPC excess level } \\
\text { 3. Hazard category and limiting harmful index } \\
\text { 4. Carcinogenicity } \\
\text { 5. Substance detection rate } \\
\text { 6. Upward trend in concentrations of a substance at long- } \\
\text { term monitoring } \\
\text { 7. Biodegradability } \\
\text { 8. Substance level of contact with population } \\
\text { 9. Bioaccumulation } \\
\text { 10. Stability } \\
\text { 11. Transformation to higher toxicity compounds } \\
\text { 12. Accumulative potential in benthal deposits } \\
\text { 13. Absorption through skin } \\
\text { 14. Relative extent of long-term effects } \\
\text { 15. Complexity of impact on the population due to cross- } \\
\text { media transitions properties of a substance }\end{array}$ \\
\hline
\end{tabular}

quality standard requires more stringent conditions than those that can be achieved by using the best available techniques, supplementary conditions should in particular be required by the permit, without prejudice to other measures that may be taken to comply with the environmental quality standards".

At the same time, in the Russian legislation, policies are being persistently introduced to replace the limit values, i.e. MPCs, with the concept of "best available technologies". For example, Article 23 of the Federal Law of 10.01.2002 No. 7-FZ (Ed. of 13.07.2015) "On Environmental Protection" ${ }^{11}$ indicates the need to create a step-by-step plan for the introduction of BAT by enterprises. The Article 26, paragraph 4, Federal Law No. 416-FZ of 07.12.2011 "On Water Supply and Sanitation" (as amended on July 29, 2017) ${ }^{11}$ states: "The requirements for the content of the plan for reducing discharges, the procedure and timing for its approval, the grounds for refusing to agree on such a plan are established by the Russian Federation Government". However, no criteria are set for determining the level of chemical pollution, which the discharges and emissions rate should be reduced to.

When developing amendments to Federal Law No. 7-FZ of 10.01.2002 "On Environmental Protection" ${ }^{11}$ Article 31, the Center made the following proposal: "In cases where environmental quality standards are more stringent than the levels attained using BAT, the application for a comprehensive environmental permit should contain information on additional measures to ensure compliance with regulations". However, this proposal was not taken into account, which resulted in the absence of the corresponding requirements in all regulatory documents related to envi-

\footnotetext{
${ }^{11} \mathrm{O}$ vodosnabzhenii i vodootvedenii: Federal'nyi zakon № 416-FZ ot 07.12.2011 g. [On Water Supply and Sanitation: Federal Law of 07.12.2011 N 416-FZ]. Konsul'tantPlyus. Available at: http://www.consultant.ru/document /cons_doc_LAW_122867/(16.03.2018) (in Russian).
} 
ronmental protection, for example, the Federal Law No. 416-FZ of 07.12.2011 "On Water Supply and Sanitation", the Russian Federation Government Decree of 9.13.2016 No. 913 "On rates of charges for environment pollution and additional coefficients" (as amended on 09.12.2017) ${ }^{12}$. This means that such an important safety criterion, as MPC is replaced by reducing emissions approach, without a legislative requirement to further reduce the pollution level to MPC values.

Thus, it is necessary to develop a single consistent system of laws and bylaws to ensure the protection of human health from chemical pollution of the environment.

Conclusion. Thus, with the optimization of legislation in the field of environmental protection, an adjustment is suggested according to the following proposals:

1. The targets are not only and not so much indicators of environmental quality as the criteria for assessing achievement of its proper conditions. They are not the standards. Therefore, it is necessary to develop a single definition and a methodology for setting targets.

2. Lists of various levels indices under control are subject to significant adjustment with the aim of creating a unified document on control with recommendations on choice of priority pollutants.

3. The RF legislation should contain a requirement on the possibility of harmonization of chemicals emissions on the basis of BAT provided that a plan for further reducing discharges and emissions to MPC levels is provided.

4. To improve the situation in the field of environmental quality management, the following measures should be taken:

1. To harmonize legislative framework in the field of environment and health protection, having eliminated contradictions on indexes and hazard criteria.

2. To improve methodic approaches to determining qualitative and quantitative composition of emissions, discharges, pollution status of various environmental objects, and choice of priority index for monitoring.

3. To improve and objectify control, expand the system of independent laboratories equipped with modern analytical tools, where all industrial enterprises would have to conduct extended studies of their discharges and emissions at certain time intervals.

4. The charges for environment pollution should be replaced by an increase or decrease in taxes with further allocation of funds saved by an enterprise for environment protection measures.

Funding. Our research was not granted any sponsors' support.

A conflict of interests. The authors state there is no conflict of interests.

\footnotetext{
${ }^{12} \mathrm{O}$ stavkakh platy za negativnoe vozdeistvie na okruzhayushchuyu sredu i dopolnitel'nykh koeffitsientakh: Postanovlenie Pravitel'stva RF № 913 ot 13.09.2016 g. (red. ot 09.12.2017 g.) [On the rates of payment for the negative impact on the environment and additional coefficients: Resolution of the Government of the Russian Federation of September 13, 2013 N 913]. Kodeks: elektronnyi fond pravovoi i normativno-tekhnicheskoi dokumentatsii. Available at: http://docs.cntd.ru/document/420375216 (16.03.2018) (in Russian).
} 


\section{References}

1. Protocol on Water and Health to the 1992 Convention on the Protection and Use of Transboundary Watercourses and International Lakes. London, 1999. Available at: https://reaties.un.org/pages/ViewDetails.aspx?src=

TREATY\&mtdsg_no=XXVII-5-a\&chapter=27\&clang=_en (24.03.2018).

2. Krasovskii G.N., Egorova N.A., Bykov I.I. Metodologiya garmonizatsii gigienicheskikh normativov veshchestv $\mathrm{v}$ vode $\mathrm{i}$ ee realizatsiya pri sovershenstvovanii vodno-sanitarnogo zakonodatel'stva [Methodology of harmonizing hygienic standards for water substances, and its application to improving sanitary water legislation]. Vestnik $R A M N, 2006$, no. 4, pp. 32-36 (in Russian).

3. Sinitsyna O.O., Zholdakova Z.I., Kharchevnikova N.V. Nauchnye osnovy edinogo ekologo-gigienicheskogo normirovaniya khimicheskikh veshchestv $\mathrm{v}$ okruzhayushchei srede [Scientific grounds for a unified ecological and hygienic standardization of chemicals concentrations in the environment]. Itogi i perspektivy nauchnykh issledovanii po probleme ekologii cheloveka $i$ gigieny okruzhayushchei sredy. In: Yu.A. Rakhmanin ed. Moscow, Nauchnoissledovatel'skii institut ekologii cheloveka i gigieny okruzhayushchei sredy im. A.N. Sysina Publ., 2001, pp. 106-123 (in Russian).

4. Sinitsyna O.O. Regional'noe normirovanie khimicheskikh veshchestv kak stadiya prinyatiya reshenii $\mathrm{v}$ sisteme sotsial'no-gigienicheskogo monitoringa i otsenki riska dlya zdorov'ya naseleniya [Regional standardization of chemicals as a stage in decision making in the system of social-hygienic monitoring and population health risk assessment]. Biomeditsina KhKhI veka: dostizheniya i perspektivy razvitiya RAEN. Moscow, 2016, pp. 319-323 (in Russian).

5. Zholdakova Z.I. Po povodu soobshcheniya S.D. Zaugol'nikova, M.M. Kochanova, A.O. Loita, I.I. Stavchanskogo «K voprosu o prognozirovanii opasnosti organicheskikh soedinenii vo vneshnei srede» [On the message by S.D. Zaugol'nikov, M.M. Kochanov, A.O. Loyt, I.I. Stavchanskiy «On issue of predicting threats caused by organic compounds in the environment»]. Gigiena i sanitariya, 1975, no. 9, pp. 7-9 (in Russian).

6. Stokgol'mskaya konventsiya o stoikikh organicheskikh zagryaznitelyakh (Stokgol'm, 22 maya 2001 g.) (s izmeneniyami i dopolneniyami) [Stockholm Convention on Persistent Organic Pollutants (Stockholm, May 22, 2001) (with amendments and supplements)]. GARANT. Available at: http://base.garant.ru/2561308/ (16.03.2018) (in Russian).

7. Rotterdamskaya konventsiya o protsedure predvaritel'nogo obosnovannogo soglasiya v otnoshenii otdel'nykh opasnykh khimicheskikh veshchestv i pestitsidov v mezhdunarodnoi torgovle [Rotterdam Convention on the Prior Informed Consent Procedure for Certain Hazardous Chemicals and Pesticides in International Trade]. KODEKS: elektronnyi fond pravovoi $i$ normativno-tekhnicheskoi dokumentatsii. Available at: http://docs.cntd.ru/document/901947565 (20.03.2018) (in Russian).

8. Agency for Toxic Substances and Disease Registry. Available at: https://www.atsdr.cdc.gov/ (26.03.2018).

9. Zholdakova Z.I., Manaeva E.S., Belyaeva N.I., Gollandtseva A.I., Mamonov R.A., Poltoratskii A.Yu., Sinitsyna O.O. Nauchnoe obosnovanie prioritetnykh pokazatelei dlya optimizatsii kontrolya za khimicheskim zagryazneniem r. Moskva [Scientific grounds for priority indexes aimed at optimizing control over chemical contamination of River Moskva]. Sovremennye metodologicheskie problemy izucheniya, otsenki $i$ reglamentirovaniya faktorov okruzhayushchei sredy, vliyayushchikh na zdorov'e cheloveka: Materialy Mezhdunarodnogo Foruma Nauchnogo soveta Rossiiskoi Federatsii po ekologii cheloveka i gigiene okruzhayush- 
chei sredy, posvyashchennogo 85-letiyu FGBU «NII ECh i GOS im. A.N. Sysina» Minzdrava Rossii: v 2-kh chastyakh, 2016, pp. 209-211 (in Russian).

10. Konventsiya o dostupe $\mathrm{k}$ informatsii, uchastii obshchestvennosti v protsesse prinyatiya reshenii i dostupe $\mathrm{k}$ pravosudiyu po voprosam, kasayushchimsya okruzhayushchei sredy [Orkhusskaya konventsiya] [Convention on Access to Information, Public Participation in Decision-making and Access to Justice in Environmental Matters [Aarhus Convention]]. Organizatsiya Ob"edinennykh Natsii: ofitsial'nyi sait. Available at: http://www.un.org/ru/documents/decl_conv/conventions/orhus.shtml (16.03.2018) (in Russian).

11. Krasovskii G.N., Egorova N.A. Metodologiya vybora otsenochnykh pokazatelei dlya gigienicheskogo monitoringa vodnykh ob"ektov [Methodology for selecting assessment parameters for hygienic monitoring over water objects]. Gigiena $i$ sanitariya, 1994, no. 6, pp. 4-9 (in Russian).

12. Onishchenko G.G., Karmazinov F.V., Kirillov V.V., Grachev V.A., Rakhmanin Yu.A., Rublevskaya O.N., Kirillov D.M., Volkova I.I., Plyamina O.V., Zholdakova Z.I., Sinitsyna O.O. Sistemnyi benchmarking kanalizovaniya, kompleksnaya otsenka i obespechenie bezopasnosti vodnykh istochnikov [System benchmarking for canalizing, complex assessment and provision of water sources safety]. St. Petersburg, Novyi zhurnal Publ., 2012, vol. 2, 464 p. (in Russian).

Zholdakova Z.I., Sinitsyna O.O., Pechnikova I.A., Savostikova O.N. Contemporary trends in harmonization of legal grounds for providing safety of environmental chemical contaminaiton for human health. Health Risk Analysis, 2018, no. 2, pp. 4-13. DOI: 10.21668/health.risk/2018.2.01.eng

Received: 23.04 .2018

Accepted: 01.06.2018

Published: 30.06.2018 